\title{
An Empirical Study on the Integration of Rural Tourism and Meteorological from the Perspective of Global Tourism
}

\author{
Jing $\mathrm{Li}^{1}$, Ping Huang ${ }^{2}$ * \\ ${ }^{1}$ Jiuquan Meteorological Bureau, Jiuquan 735000, China; \\ ${ }^{2}$ School of management, Chengdu University of Information Technology, Chengdu 610103, China \\ * Corresponding author
}

Keywords: Global Tourism; Rural Tourism; Meteorological Services; Integrated Development; Evaluation Index of Fusion Degree.

Abstract. The "global tourism" has been raised to the national strategy and the whole society's action hot spot. In 2018, the office of the State Council issued the "guidance on promoting the development of the whole region", and clearly pointed out that "tourism + meteorology" has become an important direction for promoting the development of the "global tourism". Therefore, this paper from the perspective of "tourism + meteorology" integration development, explored the influencing factors and the path of the integration and development of rural tourism and meteorological services. Building the evaluation index of the degree of integration and analyzing of the integration development of Mount Emei and Shitai County. Then, proposed some measures. Finally, exploring the way to achieve industrial upgrading and optimize tourism environment, and hope to provide a theoretical basis and practical reference to the "integration development of tourism and meteorological” model.

\section{Introduction}

In the era of mass tourism, the tourism market gradually has problems such as insufficient supply, imperfect system and so on. In 2016, the national tourism administration put forward the concept of "global tourism". The aim is to take tourism as the forerunner, use the "tourism + " strategic model to promote integration with the city, and optimize the public service and comprehensive management system[1]. The "whole area tourism" has risen to the national strategy and the new tourism theory. The model of "Tourism +" has become an inevitable choice for the coordinated development of multi industries. The development of rural tourism is an important carrier and fundamental foundation to promote the development of the "whole area tourism" [2]. Since 2016, China Meteorological Service Association has established 28 "China Natural Oxygen Bar" areas in China to promote the construction of beautiful countryside. The State Tourism Administration has announced the creation of a global tourism unit, the Leshan City where Mount Emei is located and Shitai County in Anhui Province are both national tourism demonstration zones. Therefore, rural tourism and meteorological services are the two most integrated industries.

Based on the background of the "global tourism", this paper explores the influencing factors and paths of the integration of rural tourism and meteorological services from the perspective of tourism and meteorological integration development, and collects relevant data and information needed to build a fusion degree evaluation system. Selecting the specific development situation of Shitai County and Mount Emei Scenic Area in Anhui Province, this paper evaluates and analyzes the integration degree of rural tourism and meteorological services. The specific research contents are as follows: 


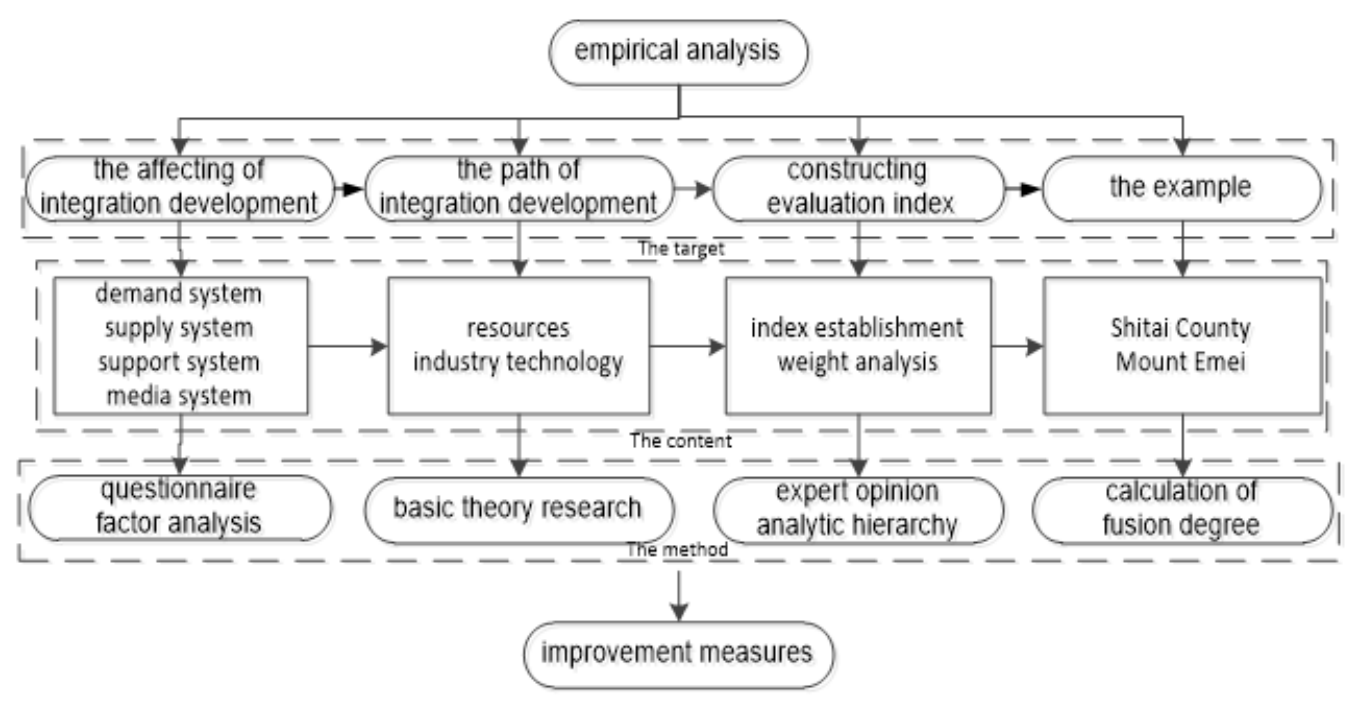

Fig.1 Research content framework

\section{Influencing Factors of Integration Development}

Under the concept of global tourism, there are still many problems in the application of "tourism + meteorology" model in enriching tourism pattern and promoting the transformation and upgrading of tourism[3]. Therefore, further promoting the integration of rural tourism and meteorological services in China has been affected by many factors[4]. This paper explores the influencing factors of rural tourism and meteorological services convergence development from four angles of demand, supply, media and support, and constructs the impact system of rural tourism and meteorological services convergence development. The correlation between various factors was analyzed.

In demand system, the driving force of tourism meteorological integration development comes from inherent demand of tourists, and service is one of the main conditions to meet the inherent demand. The integrated development of rural tourism and meteorological services is mainly through tourism meteorological services, thematic advertising, linking demand and supply[5]. The support system includes the hardware facilities of rural tourism, the infrastructure construction of rural tourism meteorology, the government guidance measures, the construction of scenic tourism meteorological management system and meteorological technical support. The media system plays an intermediary role in the integrated development impact system in the form of "tourist - media - tourist destination". In the influence system of rural tourism and meteorological service integration, the pulling effect of the supply system is mainly manifested in promoting the generation of tourism demand. On the one hand, the demand system promotes the tourism behavior and the demand for meteorological services[6]. On the other hand, the supply system and support system provide auxiliary attraction.

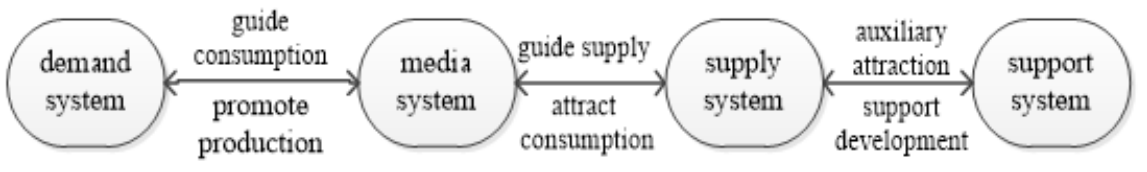

Fig. 2 Four influence system diagram

According to the current development situation of tourism meteorology, referring to the standards of "classification and coding of tourism meteorological resources" and "tourism meteorological service standard", as well as the research results and expert opinions of various scholars on the integration of tourism and meteorological development, this paper designs a questionnaire from four aspects: demand, supply, support and media, and invites experts to grade it. The influencing factors are divided into two categories: promoting effect and pulling effect. 
Table 1 The factors affecting integration development (promoting effect)

\begin{tabular}{|c|c|c|}
\hline $\begin{array}{c}\text { Influence } \\
\text { system (A) }\end{array}$ & Classification (B) & Influence factor (C) \\
\hline \multirow{8}{*}{$\begin{array}{c}\text { Demand } \\
\operatorname{system}\left(\mathrm{A}_{1}\right)\end{array}$} & \multirow{4}{*}{$\begin{array}{l}\text { The influence degree of } \\
\text { meteorological resources for tourism } \\
\qquad\left(\mathrm{B}_{1}\right)\end{array}$} & $\begin{array}{l}\text { The value of meteorological } \\
\text { Resources in rural scenic spots }\left(\mathrm{C}_{1}\right)\end{array}$ \\
\hline & & $\begin{array}{c}\text { Ecotourism value of rural scenic } \\
\text { spots }\left(C_{2}\right)\end{array}$ \\
\hline & & $\begin{array}{l}\text { The stability of meteorological } \\
\text { Resources in rural scenic spots }\left(\mathrm{C}_{3}\right)\end{array}$ \\
\hline & & $\begin{array}{l}\text { Development of tourism meteorological } \\
\text { Resources in rural scenic spots }\left(\mathrm{C}_{4}\right)\end{array}$ \\
\hline & \multirow{3}{*}{$\begin{array}{c}\text { The influence degree of development } \\
\text { level } \\
\text { In scenic area }\left(\mathrm{B}_{2}\right)\end{array}$} & Location of rural scenic $\operatorname{spots}\left(\mathrm{C}_{5}\right)$ \\
\hline & & Village scale $\left(\mathrm{C}_{6}\right)$ \\
\hline & & Number of rural scenic spots $\left(C_{7}\right)$ \\
\hline & $\begin{array}{c}\text { The influence degree of characteristic } \\
\text { village construction }\left(\mathrm{B}_{3}\right)\end{array}$ & $\begin{array}{c}\text { Degree of diversity of tourism } \\
\text { Meteorological characteristics }\left(\mathrm{C}_{8}\right)\end{array}$ \\
\hline \multirow{5}{*}{$\begin{array}{c}\text { Media } \\
\operatorname{system}\left(\mathrm{A}_{2}\right)\end{array}$} & \multirow{3}{*}{$\begin{array}{l}\text { The publicity of } \\
\text { Scenic spots }\left(B_{4}\right)\end{array}$} & $\begin{array}{l}\text { Advertising volume of tourism } \\
\text { Meteorological products }\left(\mathrm{C}_{9}\right)\end{array}$ \\
\hline & & $\begin{array}{l}\text { Tourism meteorological update } \\
\text { frequency }\left(\mathrm{C}_{10}\right)\end{array}$ \\
\hline & & Publicity of products $\left(\mathrm{C}_{11}\right)$ \\
\hline & \multirow{2}{*}{ The network popularity $\left(\mathrm{B}_{5}\right)$} & $\begin{array}{l}\text { Tourism meteorological theme } \\
\text { Network access degree }\left(C_{12}\right)\end{array}$ \\
\hline & & $\begin{array}{c}\text { Tourism meteorological forecast } \\
\text { information network access degree }\left(\mathrm{C}_{13}\right)\end{array}$ \\
\hline
\end{tabular}

Table 2 The factors affecting integration development (pulling effect)

\begin{tabular}{|c|c|c|}
\hline Influence system (A) & Classification (B) & Influence factor (C) \\
\hline \multirow{6}{*}{ Supply system $\left(\mathrm{A}_{3}\right)$} & \multirow{3}{*}{$\begin{array}{l}\text { Impact degree of tourism } \\
\text { meteorological safety }\left(\mathrm{B}_{6}\right)\end{array}$} & $\begin{array}{l}\text { Safety service for tourist } \\
\text { Meteorological zones }\left(\mathrm{C}_{14}\right)\end{array}$ \\
\hline & & $\begin{array}{l}\text { Tourism meteorological } \\
\text { Traffic safety service }\left(\mathrm{C}_{15}\right)\end{array}$ \\
\hline & & $\begin{array}{l}\text { Scenic area information } \\
\text { Service perfect degree }\left(\mathrm{C}_{16}\right)\end{array}$ \\
\hline & \multirow{3}{*}{$\begin{array}{l}\text { Influence degree of } \\
\text { Tourism weather forecast }\left(B_{7}\right)\end{array}$} & $\begin{array}{c}\text { Usage frequency of tourism meteorological service } \\
\text { platform }\left(C_{17}\right)\end{array}$ \\
\hline & & $\begin{array}{c}\text { Weather forecast service } \\
\text { For rural tourist attractions }\left(\mathrm{C}_{18}\right)\end{array}$ \\
\hline & & $\begin{array}{c}\text { Early warning } \\
\text { Information release rate }\left(\mathrm{C}_{19}\right)\end{array}$ \\
\hline \multirow{8}{*}{ Support system $\left(\mathrm{A}_{4}\right)$} & \multirow{3}{*}{$\begin{array}{l}\text { Impact degree of policy } \\
\text { Support and construction }\left(\mathrm{B}_{8}\right)\end{array}$} & $\begin{array}{c}\text { Rural tourism meteorological government } \\
\text { support }\left(C_{20}\right)\end{array}$ \\
\hline & & $\begin{array}{l}\text { Operation status of tourism } \\
\text { Meteorological scenic } \\
\text { Spot management system }\left(\mathrm{C}_{21}\right)\end{array}$ \\
\hline & & Development level of scenic spots $\left(\mathrm{C}_{22}\right)$ \\
\hline & \multirow{2}{*}{$\begin{array}{c}\text { Impact degree of } \\
\text { Infrastructure construction }\left(\mathrm{B}_{9}\right)\end{array}$} & Intelligent travel agency $\left(\mathrm{C}_{23}\right)$ \\
\hline & & Smart hotel $\left(\mathrm{C}_{24}\right)$ \\
\hline & \multirow{3}{*}{$\begin{array}{l}\text { Comprehensive degree of } \\
\text { Tourism and meteorological }\left(\mathrm{B}_{10}\right)\end{array}$} & $\begin{array}{l}\text { The degree of word of mouth } \\
\text { In tourism advertising }\left(C_{25}\right)\end{array}$ \\
\hline & & $\begin{array}{c}\text { Satisfaction degree of tourism } \\
\text { Meteorological service experience }\left(\mathrm{C}_{26}\right)\end{array}$ \\
\hline & & Compared with expected value $\left(\mathrm{C}_{27}\right)$ \\
\hline
\end{tabular}


The data were collected after the questionnaire survey, and the reliability and validity of all samples were analyzed by SPSS20.0. In the reliability analysis, check all the set-up problems and whether the correlation coefficients are in the same direction, and use Cronbach's alpha to analyze the reliability of each latent variable.

The Cronbach's alpha at all levels is $0.65-0.75$, and the total Cronbach's alpha is 0.67.After the reliability analysis of the data, the content validity of exploratory factor analysis of KMO and Bartlett test was tested by SPSS software. The KMO value of the test is $0.722>0.5$. It shows that there is a strong correlation between the selected factors.

Table 3 KMO and Bartlett's Test

\begin{tabular}{|c|c|r|}
\hline \multicolumn{2}{|c|}{ Sampling enough Kaiser-Meyer-Olkin metrics } & .722 \\
\hline \multirow{3}{*}{ Bartlett's Test } & Approximate chi square & 147.415 \\
\cline { 2 - 3 } & $\mathrm{df}$ & 36 \\
\cline { 2 - 3 } & Sig. & .000 \\
\hline
\end{tabular}

The extraction of factors and factors rotates, and the 2 principal components extracted contain 74.301\% of the original data. Component 1 mainly contains B1, B4, B6, B7 and B10, which can be summarized as factor 1. Component 2 mainly includes B2, B3, B5, B8 and B9 be summarized as factor 2.

Table 4 Rotated component matrix

\begin{tabular}{|l|c|c|}
\hline & \multicolumn{2}{|c|}{ Component } \\
\cline { 2 - 3 } & 1 & 2 \\
\hline The influence degree of meteorological resources for tourism $\left(\mathrm{B}_{1}\right)$ & .913 & .140 \\
\hline The influence degree of development level in scenic area $\left(\mathrm{B}_{2}\right)$ & .184 & .804 \\
\hline Characteristic village construction $\left(\mathrm{B}_{3}\right)$ & .236 & .698 \\
\hline The publicity of scenic spots $\left(\mathrm{B}_{4}\right)$ & .768 & .110 \\
\hline The network popularity $\left(\mathrm{B}_{5}\right)$ & .362 & .749 \\
\hline Impact degree of tourism meteorological safety $\left(\mathrm{B}_{6}\right)$ & .717 & .367 \\
\hline Influence degree of tourism weather forecast $\left(\mathrm{B}_{7}\right)$ & .835 & .235 \\
\hline Impact degree of policy support and construction $\left(\mathrm{B}_{8}\right)$ & .274 & .731 \\
\hline Impact degree of infrastructure construction $\left(\mathrm{B}_{9}\right)$ & .142 & .787 \\
\hline Comprehensive degree of tourism and meteorological $\left(\mathrm{B}_{10}\right)$ & .540 & .431 \\
\hline
\end{tabular}

According to the formula:

$$
F_{\mathrm{j}}=b_{j 1} X_{1}+b_{j 2} X_{2} \ldots+b_{j n} X_{1 n}
$$

$\mathrm{J}=1 \ldots \mathrm{m}, \quad b_{i j}=\frac{a_{i j}}{\sqrt{\lambda}}$, calculates the scores of each factor as shown in table:

Table 5 Score table of factors

\begin{tabular}{|c|c|c|c|c|c|}
\hline \multirow{2}{*}{ Factor 1} & $\mathrm{~B}_{1}$ & $\mathrm{~B}_{4}$ & $\mathrm{~B}_{6}$ & $\mathrm{~B}_{7}$ & $\mathrm{~B}_{10}$ \\
\cline { 2 - 6 } & 1.20156 & .89829 & .57672 & .53791 & .39836 \\
\hline \multirow{2}{*}{ Factor 2} & $\mathrm{~B}_{2}$ & $\mathrm{~B}_{3}$ & $\mathrm{~B}_{5}$ & $\mathrm{~B}_{8}$ & $\mathrm{~B}_{9}$ \\
\cline { 2 - 6 } & .51873 & .38440 & .17094 & .48804 & .25603 \\
\hline
\end{tabular}

The influence system of the integration of tourism and meteorology is a complex system. It is not only influenced by many main factors such as tourism meteorological resources, scenic spots propaganda, tourism meteorological safety, but also includes the interaction of the development level of scenic spots, characteristic rural construction, policy support and other object factors.

\section{Constructing Evaluation System}

The integration of rural tourism and meteorological services should focus on resources, innovation and science and technology. The innovation of system and mechanism provides a good environment for further integration and development. The development of tourism resources and product innovation open 
up a new fusion point for the integration and development of tourism and meteorology, and promote the upgrading of tourism industrial structure. The integration of science and technology solves the technical problems existing in the process of more integration and development, and provides support and guarantee for the integration and development[6]. Therefore, this article will focus on further research from three aspects: resources, technology and innovation.

At present, the best part of the integration of rural tourism and meteorological services in China is the integration of resources utilization. Therefore, based on the theoretical research of the impact system of integration development, this chapter constructs the evaluation index system of integration degree from the perspective of resources in three aspects of human meteorology, weather and landscape, climate and environment. Expert opinion method is used to select the best condition to reflect the development of integration among the various factors. Based on the above analysis, the evaluation index of rural tourism and meteorological integration is established.

Table 6 Evaluation index of integration degree between rural tourism and meteorological service resources

\begin{tabular}{|c|c|}
\hline Evaluation dimension(A) & Measure evaluation index(B) \\
\hline \multirow{3}{*}{$\begin{array}{c}\text { The resources of } \\
\text { tourism and meteorological }\end{array}$} & Ornamental value $\left(\mathrm{B}_{1}\right)$ \\
\cline { 2 - 2 } landscape's value dimension $\left(\mathrm{A}_{1}\right)$ & Rarity $\left(\mathrm{B}_{2}\right)$ \\
\cline { 2 - 2 } & Climate resource stability $\left(\mathrm{B}_{3}\right)$ \\
\cline { 2 - 2 } & Content richness $\left(\mathrm{B}_{4}\right)$ \\
\cline { 2 - 2 } The resources of & Humanistic meteorological landscape value $\left(\mathrm{B}_{5}\right)$ \\
\cline { 2 - 2 } tourism and meteorological & Popularity and influence $\left(\mathrm{B}_{6}\right)$ \\
\cline { 2 - 2 } landscape's influence dimension $\left(\mathrm{A}_{2}\right)$ & Culture and scientific research value $\left(\mathrm{B}_{7}\right)$ \\
\cline { 2 - 2 } The resources of & Internet publicity $\left(\mathrm{B}_{8}\right)$ \\
\hline tourism and meteorological & Predictability of meteorological resources $\left(\mathrm{B}_{9}\right)$ \\
\cline { 2 - 2 } landscape's development dimension $\left(\mathrm{A}_{3}\right)$ & Typical degree of landscape $\left(\mathrm{B}_{10}\right)$ \\
\cline { 2 - 2 } & Development and protection level $\left(\mathrm{B}_{11}\right)$ \\
\hline
\end{tabular}

\section{Data Collection and Calculation}

According to Sadie 1-9 scale method, and using the analytic hierarchy process to calculate the weight of the index.

First, we use the analytic hierarchy process to determine a set: $\left\{A_{1}, A_{2}, \cdots A_{n}\right\}$,Then, the importance of each index was scored separately. Finally, assign weights to each matrix. According to the formula:

$$
\begin{gathered}
w_{j}=\sum_{i=1}^{n} b_{i} a_{i j} \\
w=\sum_{i=1}^{n} b_{i} a_{i}
\end{gathered}
$$

$\sum_{j=1}^{m} a_{i j}=1, \sum_{i=1}^{n} b_{i}=1, \mathrm{w}=\left(w_{1, \ldots,}, w_{n}\right)^{T}, W_{i}>0, \quad(\mathrm{i} \in \mathrm{I})$, The results are as follows:

Table 7 Average weight calculation results

\begin{tabular}{|c|c|c|c|}
\hline Measure evaluation index(B) & Weight value & Measure evaluation index(B) & Weight value \\
\hline $\mathrm{B}_{1}$ & 0.27 & $\mathrm{~B}_{7}$ & 0.02 \\
\hline $\mathrm{B}_{2}$ & 0.12 & $\mathrm{~B}_{8}$ & 0.10 \\
\hline $\mathrm{B}_{3}$ & 0.06 & $\mathrm{~B}_{9}$ & 0.11 \\
\hline $\mathrm{B}_{4}$ & 0.09 & $\mathrm{~B}_{10}$ & 0.03 \\
\hline $\mathrm{B}_{5}$ & 0.04 & $\mathrm{~B}_{11}$ & 0.05 \\
\hline $\mathrm{B}_{6}$ & 0.11 & & \\
\hline
\end{tabular}




\section{Empirical Analysis}

Based on the specific development of Shitai County and Emeishan Mountain in Anhui Province, and combined with the evaluation index of resource utilization, this chapter evaluates and analyzes the development of resource utilization and integration of rural tourism and meteorology.

Different scholars have different ways to calculate the degree of tourism integration. One is to construct a matrix of related fusion elements, and use its correlation coefficient as fusion coefficient to calculate the fusion degree according to the variation characteristics of fusion coefficient. But the disadvantage of this method is that the amount of data needed is large and the range is wide, so it is difficult to be comprehensive in data collection. Therefore, on the basis of previous studies, the correlation coefficient is used as the fusion coefficient. Applying the calculation weight of the evaluation index of the integration degree of rural tourism and meteorological service resources, experts are invited to grade the integration according to the actual situation. Application formula:

$$
R=\sum_{i=1}^{n} w_{j} B_{j}
$$

$\mathrm{R}=$ fusion degree. It represents a quantitative index to measure the level of integration of rural tourism and meteorological services. The value range is $0-3$, the greater the value, the better the fusion. $w_{j}=$ weights. $B_{j}=$ score of the index.

In order to reflect the integrated development level of rural tourism and meteorological services more effectively and intuitively, according to the relationship between the range of values and the maximum degree of integration of individual items, the integrated development level is divided into five levels: I, II, III, IV, V, and 5 grades. The proportion of fusion is percentile ratio with fusion degree and its maximum value. As shown in the following table:

Table 8 The Fusion level classification standard

\begin{tabular}{|c|c|}
\hline Proportion of fusion \% & Level \\
\hline $0 \%-20 \%$ & I \\
\hline $20 \%-40 \%$ & II \\
\hline $40 \%-60 \%$ & III \\
\hline $60 \%-80 \%$ & IV \\
\hline $80 \%-100 \%$ & V \\
\hline
\end{tabular}

Calculate the fusion degree of Mount Emei and Shitai County scenic area separately, and get the result and grade division as follows:

Table 9 Fusion degree classification and ranking

\begin{tabular}{|c|c|c|}
\hline Number & \multicolumn{2}{|c|}{ Evaluation index and level (Fusion degree) } \\
\hline & Mount Emei Scenic Area & Shitai County Scenic Area \\
\hline 1 & $\mathrm{~B}_{1} \sim \mathrm{IV}$ （1.695） & $\mathrm{B}_{2} \sim$ III（0.696） \\
\hline 2 & $\mathrm{~B}_{6} \sim \mathrm{III}(0.646)$ & $\mathrm{B}_{8} \sim$ III $(0.520)$ \\
\hline 3 & $\mathrm{~B}_{7} \sim \mathrm{III}(0.116)$ & $\mathrm{B}_{3} \sim \mathrm{III}(0.312)$ \\
\hline 4 & $\mathrm{~B}_{11} \sim \mathrm{III}(0.292)$ & $\mathrm{B}_{10} \sim \mathrm{III}(0.156)$ \\
\hline 5 & $\mathrm{~B}_{8} \sim$ III $(0.58)$ & $\mathrm{B}_{11} \sim \mathrm{III}(0.292)$ \\
\hline 6 & $\mathrm{~B}_{9} \sim \mathrm{III}(0.602)$ & $\mathrm{B}_{1} \sim \mathrm{III}(1.242)$ \\
\hline 7 & $\mathrm{~B}_{4} \sim \mathrm{III}(0.489)$ & $\mathrm{B}_{4} \sim \mathrm{III}(0.369)$ \\
\hline 8 & $\mathrm{~B}_{2} \sim$ III $(0.580)$ & $\mathrm{B}_{5} \sim \mathrm{III}(0.168)$ \\
\hline 9 & $\mathrm{~B}_{5} \sim \mathrm{II} \quad(0.153)$ & $\mathrm{B}_{7} \sim \mathrm{II} \quad(0.076)$ \\
\hline 10 & $\mathrm{~B}_{3} \sim \mathrm{II} \quad(0.206)$ & $\mathrm{B}_{6} \sim \mathrm{II} \quad(0.396)$ \\
\hline 11 & $\mathrm{~B}_{10} \sim \mathrm{II} \quad(0.115)$ & $\mathrm{B}_{9} \sim \mathrm{II} \quad(0.330)$ \\
\hline
\end{tabular}

The integration of tourism meteorological resources between Shitai and Mount Emei has the same 
characteristics. The fusion development level is relatively average, mainly concentrated in the III level. The index of integration development in the level II is all three, and the highest integration level of Mount Emei scenic spot is IV.

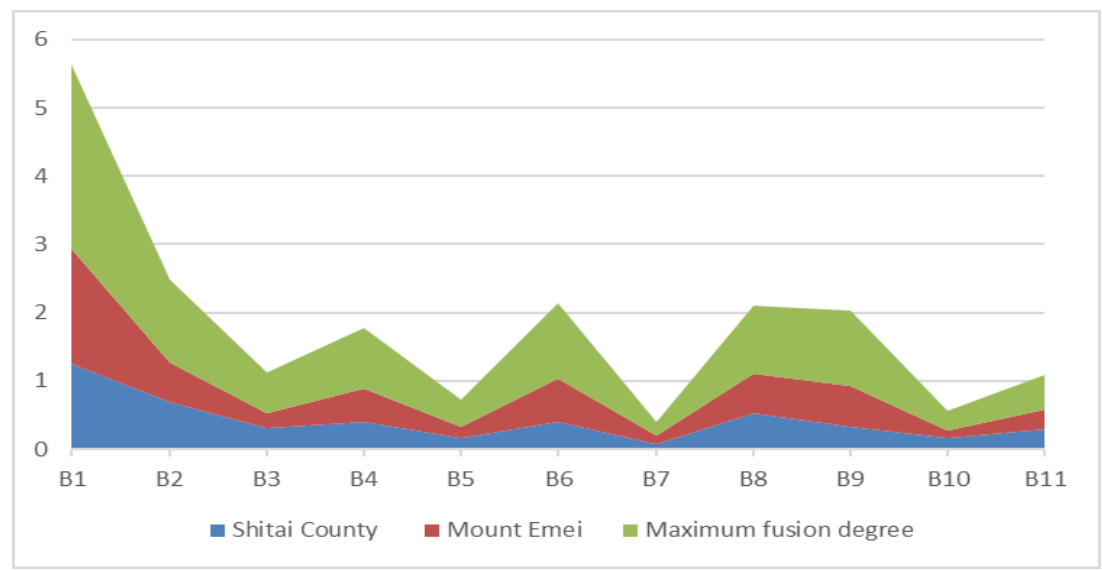

Fig.3 The fusion degree comparison of meteorological resources in tourism

The difference is: in addition to the special regional characteristics formed by rich climatic conditions, the famous scenic spots in Emei Mountain mainly rely on the ornamental landscape formed by weather and meteorological conditions. For example, snow scenery, treasure light, Buddha light and so on, the duration period, has certain ornamental period, needs the weather forecast and the forecast support. Shitai County is mainly dependent on abundant natural conditions of climatic resources. Such as rivers, karst caves, vegetation and so on, the climatic conditions are relatively stable. Shitai County was selected as "China's Natural Oxygen Bar" in 2017, so it has a high degree of integration in the stability of tourism meteorological resources. Generally speaking, Shitai County and Mount Emei Scenic Area have their own advantages in the development of tourism meteorological integration, but the overall integration level is relatively average and the overall integration degree is not high.

Through the study on the integration and development of tourism meteorological resources in Shitai County and Emei Mountain, we can see that the integration and development of rural tourism and meteorological resources in China have their own characteristics, but there are still some problems in the integration and development.

\section{Improvement Measures}

In order to further promote the integration of rural tourism and meteorological services, the paper puts forward relevant strategies and safeguards from five aspects of innovation, policy, service, technology and sustainable development.

"Innovation" safeguard measures include two aspects. One is the supply of products and exploits diversified tourism products under the conditions of integrated development of tourism and meteorology. The other is innovation system and mechanism. From the perspective of the concept and connotation of global tourism, promoting the integration of rural tourism and meteorology requires the tourism market as the main body, and the coordination mechanism and working system of up and down linkage. Establish a " $4+2 "$ model of tourism and meteorological industry integration and development from the state to the provinces, cities, counties and four levels of departments.

In safeguard measures of policy, national and local governments have provided a large number of policy supports in agriculture, tourism, ecology, meteorology and other aspects, promoting the coordinated development of tourism and various industries. In recent years, the rapid development of rural tourism cannot be separated from the support of policy environment, solving the development path of rural tourism, the source of funds, tourism and other issues of poverty alleviation.

In terms of service, the integration of tourism and meteorological industry has made some achievements under the promotion of the "global tourism", but the application of meteorological tourism 
service platform for rural tourism is still in the stage of development[7]. On the one hand, we should make use of the new science and technology to connect with the service industry, so as to realize the intelligent development of tourism meteorology. On the other hand, we should eliminate the uniqueness of tourism service products and develop diversified tourism service products. Improve rural tourism meteorology to ensure that meteorological information is updated and released in real time. Develop tourism meteorological service client, timely use of network platform, micro-blog, micro-letter and other ways to release service information, weather services and intelligent rural areas will be combined to improve the coverage of network services.

Technical safeguard measures include two aspects: talent and profession. First of all, we need to improve the efficiency of using talents and cultivate professional and compound talents. We should promote the research of tourism basic theory and practical application, and combine professional knowledge with local reality. Carrying out activities such as meteorological Publicity Day and accelerate the modernization of tourism meteorology and informatization.

The last is safeguards for sustainable development, including sustainable development of meteorological resources and products in tourism[8]. When developing new tourism products, we must pay attention to protecting the ecological environment. According to the characteristics of regional geography and culture, we should rationally plan the construction and development of tourism ecological regions, Innovating product supply and seeking more integration points to cope with the increasing competitiveness of tourism market

\section{Summary}

This paper is based on the concept of "global tourism" and chooses "tourism + meteorology" model to study the integration of development. As the integration of tourism and meteorology is still in its infancy, the relevant research results are few, so the integration of rural tourism and meteorological services development direction and form need to be further explored. In the context of global tourism, "tourism + meteorology" integration and development is a new direction to innovate the tourism pattern, theoretical research will also become a new research perspective. In the future, more academic and human resources should be attracted to promote the integration of rural tourism and meteorological services.

\section{Acknowledgement}

This research is granted by 2016 soft science program of Sichuan Technology Bareau: "Innovation System Research of Tourism New Operation under the Background of Internet +". Project Number is $2016 Z R 0095$.

\section{Reference}

[1]. Zuo Wenjun, Ming Qingzhong, Li Yuanyuan. Study on the Characteristics, Development Motivation and Realization Path of Global Tourism [J].Journal of Leshan Normal University, 2016, 3111:91-96+136

[2]. Sun Huang Hong, Wang Xiaojun. Current situation and analysis of rural tourism development in China [J]. farmer's staff, 2017,08:7-9

[3]. Liu Tong. Study on the impact of meteorology on tourism [D]. Dongbei University of Finance and Economics, 2011

[4]. Tianli, Zhang Pengyang. Literature Review and Research Framework Construction of Tourism Industry Integration [J].Techno-economic and Management Research, 2016 (09): 119-123

[5]. Zhang Wenjing, Xu Qing. Visual Analysis of Knowledge Map of International Rural Tourism Research [J/OL]. Zhejiang Agricultural Sciences, 2018 (03): 519-524 
[6]. Deng Ling, Zhu Ding Zhen. Summary of theoretical research on meteorological services in China [J]. meteorological and disaster mitigation research, 2015,38 (02): 1-7

[7]. Wang Guohua. On the Ways and Methods of Implementing Global Tourism Strategy [J].Journal of Beijing United University (Humanities and Social Sciences Edition), 2017,15 (03): 12-18

[8]. Li Yuyong, Wang Sijia. Construction of tourism meteorological disaster warning capability: [J]. Qinghai meteorological, 2015,02:60-65s

[9]. Zhang Yi, Qiu Jiewei, Shao Lintao, et al. [J]. Structure of Rural Tourism Pull Motivation and Type of Tourists. Resources and Environment in Arid Areas, 2014, 28 (10): 191-196

[10]. Jing Li, Ping Huang. Study on the Status and Development of Tourism Meteorological Disaster Emergency Warning System [A]. In: ICSSM 2017 Organization Committee. The Third International Conference on Social Science and Management 2017[C]. Xi’an: DEStech Publications, Inc. 2017

[11]. Li Ruiying, Liu Jinyun. Current situation and suggestion of tourism meteorological service [J]. modern agricultural science and technology, 2016, (19): 215-216

[12]. Lu Lin. Research on the capacity building of public meteorological services in China [D]. Yunnan University, 2013

[13]. Shi Peihua. The Path and Key Points of the Integration of Tourism and Other Industries [J].Journal of Tourism, 2011, 26 (05): 9-10 